\title{
The Development Process of Higher Order Thinking Skills Based Poetry Text Assessment Tools on VIII Grade Students of Junior High School Brigjend Katamso II Medan
}

\author{
Erlina Sihombing1, Mutsyuhito Solin ${ }^{2}$, M. Oky Fardian Gafari² \\ ${ }^{I}$ Master Student in Universitas Negeri Medan (Unimed), Medan, Indonesia \\ ${ }^{2}$ Lecturer in Universitas Negeri Medan (Unimed), Medan, Indonesia \\ erlina_sihombing50@yahoo.com
}

\begin{abstract}
This study is aimed describe the process of developing higher order thinking skills based poetry text assessment tools. Students need to be trained in their thinking skills by giving students the type of Higher Order Thinking Skills (HOTS) that can be used to improve students' thinking skills. This research was conducted in Junior High School Brigjend Katamso II Medan. The result shows that Preliminary studies were research and gathering preliminary information, namely needs analysis. The needs analysis in this research development began by distributing questionnaires to the needs of eighth grade students of Junior High School Brigjen Katamso II Medan, amounted to 35 students and 2 Indonesian language teachers of Junior High School Brigjen Katamso II Medan. The results of the needs analysis were as follows: That $100 \%$ of the teachers stated that they knew the assessment tools and 70\% knew the steps in preparing the assessment tools. However, only $0 \%$ of teachers test their assessment tools before use so that 100\% of teachers need a valid, effective and practical assessment tool.
\end{abstract}

Keywords: development process; assessment tools; poetry text higher order thinking skills.

\section{Introduction}

The change of continual curriculum cannot be easily followed by educators. Although the guidelines for assessment activities have been designed by Ministry of Education and Culture in such a way, not all educators are able to carry out assessment activities in accordance with these guidelines. The Chairman of Teacher Discussion Forum, Retno Listyarti (in Syarwan, 2014: 102), said that the training provided by the ministry for 52 hours in the first few months of the 2013/2014 academic year was inadequate to prepare educators to implement the new curriculum. Even the research results of the Federation of Indonesian Teachers Unions (FSGI, 2013) concerning training and preparation for the implementation of the 2013 curriculum in 17 districts / cities in 10 provinces in the country show that training does not change the mindset of educators in the learning and assessment process. This is the reason for the lack of readiness of educators in applying learning and assessment based on the 2013 curriculum in the classroom, so that errors often occur when making assessments. In practice, it is not easy to make and develop assessments that can measure in three aspects of the assessment aspects. What's more the influence of previous curriculum habits makes educators more focused on the cognitive realm only.

Appraisal tools developed by teachers often appear public exposures such as, "Score 20 if the writing is complete", while the characteristics of complete writing have not been spelled out in detail. Two schools that also experienced obstacles in designing an ideal assessment tool, especially in learning to write scientific papers in Indonesian language subjects was SMP Negeri 1 Wajak and SMP PGRI 01 Wajak. It is known that so far they have not developed adequate assessment tools in learning to write scientific papers. The appraisal tool developed also still does not show details of the criteria on the aspects which are the target of assessment, so the appraisal tool developed can be ascertained as invalid and unreliable. 
Making the Higher Order Thinking Skills (HOTS) based assessment tools is not easy. Apart from having to pay attention to the validity of the equipment, the reliability of the results of the use of the assessment tool also needs to be carefully considered. Thus, the same assessment tools for the same competence can be used in different schools and students.

Poetry / literature learning is very important because it can help students play roles with their feelings. According to Kosasih (2011: 206) said poetry is a form of literary work using words that are beautiful and rich in meaning. Through poetry can help students express feelings of happiness, sadness, and joy in written and oral form.

Poetry learning in Junior High School in accordance with 2013 Curriculum aims to improve students' skills in speaking appropriately and creatively, improve the ability to think logically, critically and reason, and increase the sensitivity of feelings and the ability of students to understand and enjoy literary works. In addition, poetry learning is intended so that educated students become human beings who are personality, polite, civilized, and refined in character, have a sense of humanity, social care, and have cultural appreciation, channeling ideas, imagination, and creative expression both verbally and in writing.

Students need to be trained in their thinking skills by giving students the type of Higher Order Thinking Skills (HOTS) that can be used to improve students' thinking skills. The question is created by applying basic competencies that can be used to measure higher-order thinking skills of students. Given the role of assessment that can be a motivation and challenge for improving the quality of educational competitiveness, the authors are interested in conducting a study entitled "Development of Higher Order Thinking Skills Based Poetry Text Assessment Tools in VIII Grade Students Junior High School Brigjend Katamso II Medan".

Higher Order Thinking Skills based Assessment to measure the dimensions of knowledge of students can use the form of subjective tests and objective tests. Subjective tests are test forms of description. Description form tests are items containing questions or assignments for which answers or workmanship must be done by expressing the minds of test takers. The distinctive feature of the description test is that the answer to the question is not provided by the compiler of the questions, but must be arranged by the test taker. Item type description, consisting of questions and answers must be fully thought out by students. Therefore, the skill in expressing thoughts in written form will greatly contribute to answering the questions in the description. Forms of questions like this are excellent for measuring learning outcomes at the level of analysis, evaluation, and creation.

\section{Literature Review}

\subsection{Definition of Assessment}

Education Assessment according to Permendikbud Number 20 of 2007 concerning Educational Assessment Standards is the process of gathering and processing information to determine the achievement of student learning outcomes. The principles and standards of assessment emphasize two main ideas namely assessment must improve student learning and assessment is a valuable tool for making teaching decisions (Van de Walle, 2007: 78). Assessment is not just about data collection of students, but also its processing to obtain an overview of the process and learning outcomes of students. Assessment does not just give students a question then finish, but the teacher must follow it up for the sake of learning. To carry out assessment, teachers need assessment instruments in the form of questions both to test cognitive abilities, affective, and psychomotor. 
Assessment is an activity that cannot be separated from general learning activities. All learning activities carried out must always be followed or accompanied by assessment activities. It would be unusual if there was a learning activity carried out by a teacher in the classroom without ever being followed by an assessment. Without conducting an assessment, it is not possible to assess and report the learning outcomes of students objectively (Nurgiyantoro, 2013: 3). Arifin (2009: 5) says that assessment must be seen as one of the important factors that determine the success of the process and learning outcomes, not just as a means used to assess learning outcomes.

\subsection{Test Assessment Techniques}

Written tests is a set of question items and / or statements that teachers plan systematically to obtain information about students. This test cannot be used affective to evaluate students' psychomotor skills. However it can be used to evaluate the principles that accompany skills including cognitive and psychomotor skills.

Kasueri (2014: 70) says that a written test is a set of questions or written assignments that are planned to obtain information about the test taker's abilities. Written tests require test takers' answers as a representation of their abilities. There are several forms of test assessment techniques.

This explanation is reinforced by Arifin (2012: 130) who explained the test is a technique or method used in carrying out measurement activities, in which there are various questions, statements or series of tasks that must be done or answered by students to measure aspects of student behavior.

\subsection{Higher Order Thinking Skills}

The latest revision in 2013 Curriculum in effect is focused on refining two major parts of the curriculum, namely the content standards and assessment standards. The content standard is designed so that students are able to think critically and analytically in accordance with international standards by reducing irrelevant material and deepening and expanding the material relevant to students, while the assessment standard is done by adapting international standard assessment models gradually. Assessment of learning outcomes focuses more on higher order thinking skills (Kemendikbud, 2017).

Higher-order thinking skills can be trained in the learning process in the classroom. Learning that is done must provide space for students to find the concept of activity-based and meaningful knowledge. Therefore, in the revision of 2013 Curriculum stressing must integrate (Higher Order Thinking Skills / HOTS) in learning. This shows learning must provide training not only for students 'fundamental learning of conceptual understanding, but also students' high-level abilities. Furthermore, to facilitate understanding in this article, Higher Order Thinking Skills will be written by HOTS. But in fact, the application of HOTS learning is not an easy thing to do by the teacher. The teacher must really master the material and learning strategies and the teacher is also faced with challenges with the student environment.

\subsection{Development of Poetry Text Assessment Tools Based on Higher Order Thinking Skills}

Devi in Rochmah \& Asih (2015: 29) argues that there are several ways that can be used as a guideline for question authors to write items that require higher-order thinking, namely the material to be asked is measured by behavior in accordance with the revised Bloom cognitive domain at the level of analysis (C4), evaluation (C5), and creations (C6). Each question is given 
a basic question (stimulus) and questions measure critical thinking skills. In order for items to demand higher-order thinking, each item is always given a basic question (stimulus) in the form of sources or reading material such as: reading texts, paragraphs, texts, drama, fragments of novels / stories / fairy tales, poems, cases, pictures, graphics , photos, formulas, tables, word lists / symbols, examples, maps, and films / sound recordings.

\subsection{Definition of Poetry}

Poetry is one type of literary work that represents the feelings of the author, or often also referred to as an imaginative expression of feelings. Etymologically poetry comes from the Greek word "Poesis" which means to build, shape, create, and create (Samosir, 2013: 18). Samosir (2013: 19) also explained that, poetry is a human creation in the form of expressions of the soul that are displayed expressively, poured in the form of beautiful language, aesthetic words, elegant sound series, and have an appeal to the reader. Poetry is also interpreted as one form of beautiful and rich literary works. The beauty of a poem is caused by physical elements (diction, judgment, concrete words, figure of speech, rhythm, rhythm, and typography), and mental elements (themes, mandate, feelings, atmosphere, and tone).

In general poetry can be interpreted as the oldest form of literature or literary work (Herman, 1987: 1). Poetry is a means of expression, expression of anxiety or anxiety. Writing poetry is required to be good at improvising conditions into a series of words that are readable, there is a sense and meaning in each word and line that is sung in poetry (Yunus, 2015: 64). According to Waluyo in (Wardoyo, 2013: 19) that poetry is a form of literary work that expresses the thoughts and feelings of poets imaginatively and is composed by concentrating all the power of language, by concentrating the physical structure and inner structure.

\section{Research Method}

This research was conducted at Junior High School Brigjend Katamso II Medan of VIII grade. The school is located on J1. Marelan Raya Pasar 3/19, Kelurahan Rengas Pulau, Lk. XII, Medan Marelan. The study was conducted in odd semester 2019.

\section{Discussion}

This research is a research development, so the product of this study is Higher Order Thinking Skills based assessment tool. The objectives of this development research are (1) Describe the process of developing Higher Order Thinking Skills based poetry text assessment tools. (2) Describes the validation of Higher Order Thinking Skills based poetry text assessment tools based on expert judgment. (3) Describe the results of a trial of the Higher Order Thinking Skills based poetry text assessment tools. Analysis of the data and research results obtained at each stage of development are presented as follows.

This stage begins with the study of literature relating to the problem being examined as well as the formulation of a research framework. At this stage the researcher analyzes the issues raised by the researcher in the form of an analysis of the needs of teachers and students. The following researchers present the results of the analysis of the needs of teachers and students. 


\subsection{Analysis of the Needs}

Researchers collected information based on observations of the assessment tools in VIII grade student of Junior High School Brigjend Katamso II in Medan, showing that the assessment tools used by the teachers so far were only assessments that had been published by the Government without any other handbook. This proves that so far learning in schools has only focused on assessments that are already in the book. The quality of learning becomes low when the teacher uses only conventional assessments without creativity to develop the assessment. Conventional assessment tools mean the questions presented in them are not necessarily in accordance with the experiences and needs of students in achieving higher-order thinking skills. Available assessments are less supportive of students 'higher-order thinking skills and are less interesting because they only contain questions that test students' low-thinking abilities.

After that, the researcher also distributed questionnaires to 2 teachers to get initial information about the Poetry Text Assessment Tools Based on Higher Order Thinking Skills. Based on the analysis of the questionnaire needs, it can be concluded that the teacher has knowledge of the importance of assessment tools in the implementation of teaching and learning especially can help improve thinking skills high level of learners. The results of the teacher's answers above can be seen that $100 \%$ of teachers said they knew the assessment tools and $70 \%$ knew the steps in preparing the assessment tools. However, only $0 \%$ of teachers test their assessment tools before use so that $100 \%$ of teachers need a valid, effective and practical assessment tool.

\subsection{Analysis of Students}

Analysis of students is about the characteristics of students in the study site. Student analysis includes learners 'cognitive development and learners' backgrounds. To find out the characteristics of students, in the initial observation researchers conducted interviews with teachers in the field of Indonesian language studies.

Based on observations and interviews from Indonesian language teachers, it can be seen that Indonesian language knowledge of VIII grade students at Junior High School Brigjend Katamso II Medan is varieties. There are less, medium and high ability. This shows that there are factors of interest that each student has different towards Indonesian language learning.

There are several factors that become the background that can affect the level of thinking of students. One of them is the socioeconomic status possessed by each student. Through interviews with VIII grade junior high school teacher Brigjend Katamso II Medan, namely that the work of the students' parents varied, including civil servants (Teachers, Police, Soldiers), traders, laborers, private employees and others. But overall the socioeconomic background of parents of students is in the middle and lower middle categories. This condition certainly affects the thinking ability of students because most of their parents are busy working to meet their daily needs and do not have enough time to accompany children to learn at home.

At this stage the researcher conducts a review of the assessment standards. Review of assessment standards is done by making core competencies (CC), basic competencies (BC), and indicators. The core competencies and basic competencies chosen for the development of this product are:

\section{a. Core Competencies:}

KI 1 Appreciate and live the teachings of the religion they hold 
KI2 Appreciate the honest, disciplined, polite, confident, caring, and responsible behavior in interacting effectively in accordance with the development of children in the environment, family, school, community and the natural environment around, the nation, country and the regional region.

KI3 Understand and apply factual, conceptual, procedural, and metacognitive knowledge at a simple technical and specific level based on curiosity about science, technology, art, culture with human, nationality, and state insights related to phenomena and eye-sighting events.

KI4 Demonstrates the skills of reasoning, processing, and serving creatively, productively, critically, independently, collaboratively, and communicatively, in the realm of concrete and abstract domains in accordance with what is learned in schools and other similar sources in the theoretical point of view.

\section{b. Basic Competency (KD) and Indicators}

Table 1. KD Mapping and Indicators

\begin{tabular}{|c|c|}
\hline Basic competencies & Indicators \\
\hline \multirow[t]{2}{*}{$\begin{array}{l}\text { 3.7 Identifying the building blocks of } \\
\text { poetic texts that are played or read. }\end{array}$} & $\begin{array}{l}\text { 3.7.1. Students are able to formulate the } \\
\text { concept of understanding poetry texts } \\
\text { through observing poetry text models. }\end{array}$ \\
\hline & $\begin{array}{l}\text { 3.7.2 Students are able to identify the building } \\
\text { blocks of poetry and their types. }\end{array}$ \\
\hline $\begin{array}{l}\text { 4.7 Summing up the building elements } \\
\text { and the meaning of the poetic text } \\
\text { that is played or read }\end{array}$ & $\begin{array}{l}\text { 4.7.1 Students are able to make conclusions } \\
\text { about the meaning and elements of } \\
\text { building poetry texts that are played or } \\
\text { read. }\end{array}$ \\
\hline \multirow{2}{*}{$\begin{array}{l}\text { 3.8. Examining the elements of poetry } \\
\text { texts (struggle, environment, } \\
\text { romance, social conditions, } \\
\text { religious and advice) that are heard } \\
\text { or read. }\end{array}$} & $\begin{array}{l}\text { 3.8.1 Learners are able to formulate the } \\
\text { elements forming the poetry text. }\end{array}$ \\
\hline & $\begin{array}{l}\text { 3.8.2 Students are able to identify poetry- } \\
\text { building elements such as content, use of } \\
\text { language, and words (connotation and } \\
\text { denotation) in poetry. }\end{array}$ \\
\hline \multirow{2}{*}{$\begin{array}{l}\text { 4.8 Present ideas, feelings, and } \\
\text { opinions in the form of poetry texts } \\
\text { in writing / orally by paying } \\
\text { attention to the elements of poetry } \\
\text { builder. }\end{array}$} & $\begin{array}{l}\text { 4.8.1 Learners are able to write poetry based on } \\
\text { context }\end{array}$ \\
\hline & $\begin{array}{l}\text { 4.8.2 Students are able to present ideas, feelings } \\
\text { and views of the writer through poetry } \\
\text { that is read. }\end{array}$ \\
\hline
\end{tabular}

Poetry Text Material Based on Higher Order Thinking Skills. The next step is to conduct a literature study to collect poetry text material. 


\section{c. Questionnaire Grid Responses / Responses}

The second stage consists of making the appraisal apparatus grid which becomes the appraisal criteria based on Higher Order Thinking Skills. The appraisal grid that will be used is the validation sheet, teacher questionnaire and student response. The validation sheet is used to determine the appropriateness of the Higher Order Thinking Skills-based appraisal based on guidance and evaluation from material and evaluation experts. Lattice instrument of material feasibility and evaluation can be seen in appendix 3 .

Table 4. Teacher's Response of Questionnaire Grid

\begin{tabular}{|l|l|}
\hline No. & Indicators \\
\hline 1 & The overall appraisal appearance is interesting \\
\hline 2 & The language used in assessment tools is easy to understand \\
\hline 3 & Presentation of poetry text material in an assessment tool is arranged systematically \\
\hline 4 & Poetry texts in the assessment tools are in accordance with the learning objectives \\
\hline 5 & Use of question instructions in clear assessment tools \\
\hline 6 & $\begin{array}{l}\text { Learning assessment tools stimulate higher order thinking skills (Higher Order } \\
\text { Thinking Skills) }\end{array}$ \\
\hline 7 & The types of activities in the assessment tools vary \\
\hline 8 & Test questions in the assessment tools according to learning \\
\hline 9 & Use of time in accordance with existing rules \\
\hline 10 & Assessment tools help students think at a high level in poetry text learning material \\
\hline 11 & The assessment tools are different from the usual teaching materials \\
\hline 12 & Assessment tools can be studied independently by students \\
\hline 13 & Assessment tools train to enrich students' knowledge \\
\hline 14 & Assessment tools make it easier for teachers to evaluate students \\
\hline 15 & $\begin{array}{l}\text { Assessment tools make it easy for students to express their opinions in the form of } \\
\text { tests }\end{array}$ \\
\hline
\end{tabular}

Student response questionnaire sheets are also used to determine the practicality of the product in the form of assessment tools based on Higher Order Thinking Skills. This instrument was arranged to get data about students' opinions on learning. The following is a questionnaire sheet on the responses of students.

Table 3. Student's Response of Questionnaire Grid

\begin{tabular}{|l|l|}
\hline No. & Indicators \\
\hline 1 & This assessment tool makes me happy to learn it \\
\hline 2 & $\begin{array}{l}\text { Presentation of poetry texts in assessment tools starts from easy to difficult and from } \\
\text { concrete to abstract }\end{array}$ \\
\hline 3 & This assessment tool makes questions that encourage me to think at a higher level \\
\hline 4 & $\begin{array}{l}\text { The presentation of poetry texts in this assessment tool encouraged me to be able to } \\
\text { answer the test questions used }\end{array}$ \\
\hline 5 & This device encourages my curiosity \\
\hline
\end{tabular}




\begin{tabular}{|l|l|}
\hline 6 & $\begin{array}{l}\text { This assessment tool contains multiple choice tests and essays that can test how far I } \\
\text { understand the poetry text }\end{array}$ \\
\hline 7 & The language used is simple and easy to understand \\
\hline 8 & The letters used are simple and easy to read \\
\hline 9 & The use of this assessment tool makes me more directed and coherent \\
\hline 10 & This appraisal tool is interesting \\
\hline 11 & Using this assessment tool can increase the desire to learn \\
\hline 12 & This assessment tool can make learning poetry texts for higher-order thinking \\
\hline
\end{tabular}

The description of the product Poetry Text Assessment Tools Based on Higher Order Thinking Skills in Junior High School of Brigjend Katamso II Medan as follows:

a. Product Identity

Physical Material : Printed Material

Title

: Higher Order Thinking Skills based poetry text assessment tools

Material

: Poetry Text

Target

: VIII Grade Students of Junior High School Brigjend Katamso II Medan

Author Name

: Erlina Sihombing

1. Book Cover

The cover of the book with poetry text material has a front and behind. The following explanation:

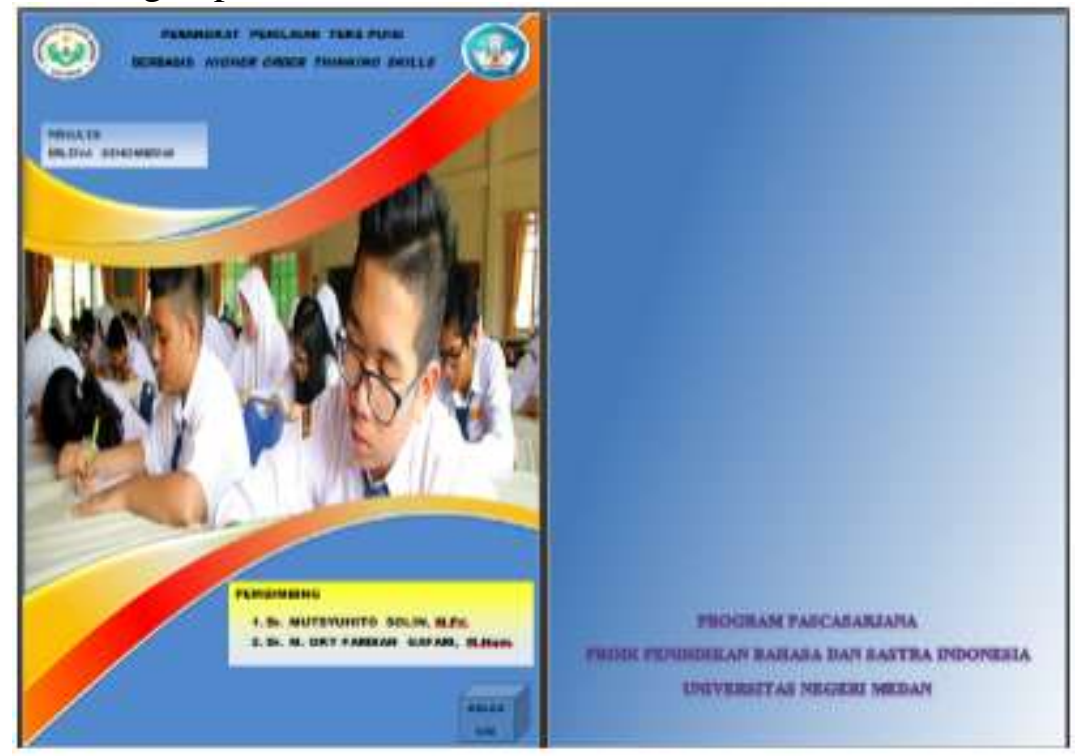

Figure 1. Cover

The front cover of the assessment tool consists of the name of the compiler, the title of the assessment tool is adjusted to the material developed, the background is adjusted to the assessment contained in the book, visible pictures of junior high school students' activities are working on the problem, this is intended so that the reader is able to know the meaning of the title and illustration before open the contents of the assessment tool. 


\section{Foreword}

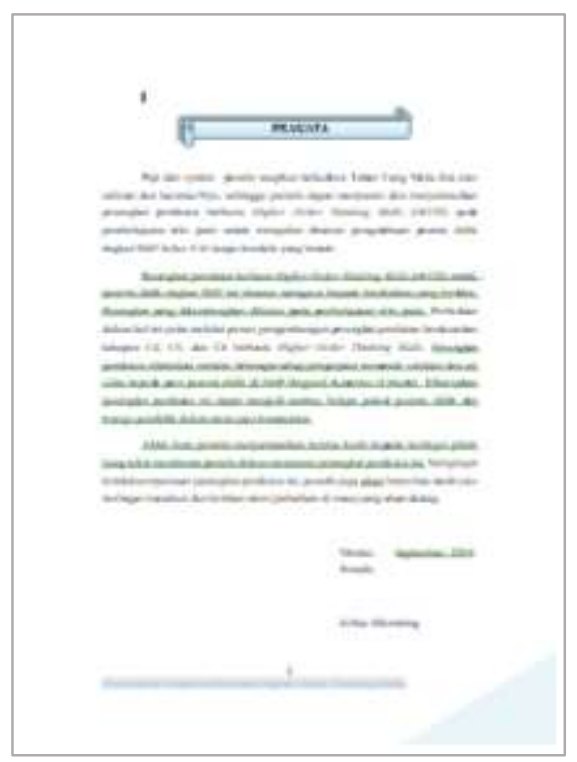

Figure 2. Foreword

The foreword is placed on the start page of the book as an opening communication between the author and the reader. The contents of the foreword is the author's attempt to communicate with the reader, by applying several types of principles, namely; 1) provide a statement that the appraisal tools are arranged appropriately and it is important to read and study, 2) The superiority of the content is presented in the appraisal apparatus, 3) The writer's expectations relating to the prospects for education and the perfection of the appraisal apparatus.

\section{Learning Activities}

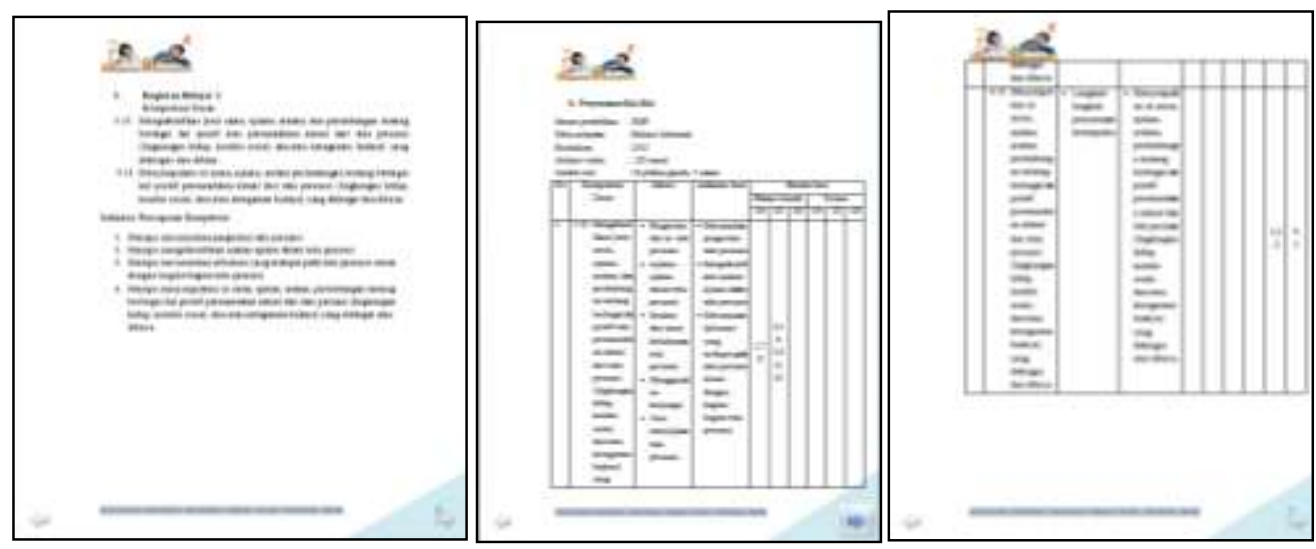

Figure 3. Learning Activities

Learning material contains material that has been determined in accordance with KI, $\mathrm{KD}$, indicators, and learning objectives with the expectation that teachers and students can find out the results obtained. 


\section{Bibliography}

Bibliography contains reference to reading material that is relevant to the poetry text material contained in the assessment tool.

The first stage carried out in this research is conducting a preliminary study that begins with a needs analysis. Based on the theory cited by Sunita \& Jha (2011: 263), needs analysis is the process of determining the priority of educational needs, gathering information, and solving problems. A needs analysis is carried out to obtain information about the assessment tools that fit the needs. From the results of a needs analysis questionnaire conducted on 2 Indonesian language teachers at Junior High School Brigjend Katamso II Medan, with the teacher's answers known that $100 \%$ of the teachers stated that they knew the assessment tools and $70 \%$ knew the steps to prepare the assessment tools. However, only $0 \%$ of teachers test their assessment tools before use so that $100 \%$ of teachers need a valid, effective and practical assessment tool.

Based on the results of the needs analysis it can be concluded that the Higher Order Thinking Skills based poetry text assessment tools is needed by the teacher in the learning process to improve the quality of learning. It aims to make students think at a high level of learning. Next, the researcher designed a Higher Order Thinking Skills based poetry text assessment tools.

The second stage, design and design an assessment tool that will be developed based on data that has been obtained from the initial stage, namely by determining the Core Competencies, Basic Competencies, and indicators as the basis for developing the assessment tools. Higher Order Thinking Skills based poetry text assessment tools developed have fulfilled the requirements as learning appraisal tools for eligible junior high school students according to Badru Zaman (2006: 7-8) that is in accordance with the applicable education program so that the making of assessment tools based on Higher Order Thinking Skills such as, preparation of tests, media selection, format selection, and initial design results.

\section{Conclusion}

The process of developing Higher Order Thinking Skills based poetry text assessment tools in Indonesian language subjects in Junior High School of Brigjen Katamso II Medan goes through several stages, namely;

Preliminary studies were research and gathering preliminary information, namely needs analysis. The needs analysis in this research development began by distributing questionnaires to the needs of eighth grade students of Junior High School Brigjen Katamso II Medan, amounted to 35 students and 2 Indonesian language teachers of Junior High School Brigjen Katamso II Medan. The results of the needs analysis were as follows: That $100 \%$ of the teachers stated that they knew the assessment tools and $70 \%$ knew the steps in preparing the assessment tools. However, only $0 \%$ of teachers test their assessment tools before use so that $100 \%$ of teachers need a valid, effective and practical assessment tool.

Initial product development begins with: (1) preparation of tests, (2) Media selection (3) Format selection (4) The results of the initial design by compiling story boards, making layouts with regard to color and composition and filling layouts with activities. 
Budapest International Research and Critics in Linguistics and Education (BirLE) Journal

Volume 2, No 4, November 2019, Page: 315-328

e-ISSN: 2655-1470 (Online), p-ISSN: 2655-2647 (Print)

www.bircu-journal.com/index.php/birle

emails: birle.journal@gmail.com

birle.journal.qa@gmail.com

\section{References}

Abdurrahim. (2011). Pengembangan Model Pembelajaran Berbasis Proyek Untuk Meningkatkan Kompetensi Siswa Pada Pembelajaran Teknologi Informasi dan Komunikasi (TIK) di Madrasah Aliyah Kota Bima. (Thesis). Jurusan Pengembangan Kurikulum SPS UPI. Tidak Dipublikasikan.

Abidin, Y. (2015). Pembelajaran Bahasa Berbasis Pendidikan Karakter. Bandung: Refika Aditama.

Abosalem, Y. (2016). Assessment Techniques and Students Higher Order Thinking Skills. International Journal og Secondary Education, Vol. 4. No.1.

Anderson and Krathwohl. (2001). A Taxonomy for Learning, Teaching, and Assessing (A Revision of Bloom's Taxonomy of Educational Objectives). Abridge Edition. New York: David McKay Company.

Arifin, Z. (2009). Evaluasi Pembelajaran. Bandung: PT Remaja Rosdakarya.

Arikunto, S. (2012). Prosedur Penelitian: Suatu Pendekatan Praktik. Jakarta: PT Rineka Cipta. (2011). Dasar-Dasar Evaluasi Pendidikan. Bumi Aksara. Jakarta

Baribin, R. (1990). Teori dan Apresiasi Puisi. Semarang: IKIP Press.

Barnett, J. E and Francis, A.L. (2012). Using higher order thinking questionsto foster critical thinking: a classroom study. Educational Psychology: An International Journal of Experimental Educational Psychology. Vol. 3, No. 2, p: 209

Borg and Gall. (1987). Educational Research An Introduction. New York: Longman.

Covacevich, C. (2014). How to select an instrument for assessing student learning. Amerika: Inter-American Development Bank.

Depdiknas. (2006). Panduan Pengembangan Program Penilaian Kelas. Jakarta: Depdiknas.

Djiwandono, S. (2013). Tes Bahasa: Pegangan bagi Pengajar Bahasa. Jakarta: Indeks. (2011). Tes Bahasa Pegangan Bagi Pengajar Bahasa. Jakarta Barat: Indeks.

Djuanda, Dadan. 2008. Pembelajaran Keterampilan Berbahasa Indonesia di Sekolah Dasar. Bandung: Pustaka Latifah.

Ediawati, A., I Nym Sudiana, Ni Md Rai Wisudariani. (2016). Penilaian Autentik dalam Pembelajaran Menulis Teks Ulasan di Kelas VIIIA-9 SMPN 1 Singaraja. Jurnal Pendidikan Bahasa dan Sastra Indonesia: Vol: 5, No.3.

Ennis, R.H. (1985). Goals for A Critical Thingking Curriculum. Costa, A.L. (Ed). Developing Minds A Resource Book for Teaching Thingking. Alexandra, Virginia: Associationfor Supervisions and Curriculum Development (ASCD)

Ganie, T. N. (2015). Buku Induk Bahasa Indonesia. Yogyakarta: Araska.

Hanna, G.S. (1993). Better teaching trough better measurement, Harcourt barce jonavovich collage pub, new York.

Hardy, G.H. (2015). A Mathematician's Apology. Alberta :University of Alberta Mathematical Sciences Society.

Hidayah, A. (2013). "Pengembangan Penilaian Unjuk Kerja Berbasis Pembelajaran Inkuiri Pada Materi Fisika SMP/MTs Pokok Bahasan Suhu dan Pemuaian". Skripsi S1.Yogyakarta: Program Studi Pendidikan Fisika.

Higher Order Thinking Skills Siswa SMPS IT Darul ARUL Azhar Berdasarkan Taksonomi Bloom Revisi oleh Harry Yusmanto dkk.

Kadir, A. (2015). Menyusun dan Menganalisis Tes Hasil Belajar. Jurnal Alta'dib. Vol 8 No 2 (online). Tersedia di http://ejournal.iainkendari.ac.id. Accessed on 16 December 2016. 
Budapest International Research and Critics in Linguistics and Education (BirLE) Journal Volume 2, No 4, November 2019, Page: 315-328 e-ISSN: 2655-1470 (Online), p-ISSN: 2655-2647 (Print) www.bircu-journal.com/index.php/birle emails: birle.journal@gmail.com birle.journal.qa@gmail.com

Kemendikbud. (2014). Permendikbud Nomor 104 Tahun 2014 tentang Penilaian Hasil Belajar Oleh Pendidik Pada Pendidikan Dasar dan Pendidikan Menengah. Kementrian Pendidikan dan Kebudayaan RI, Jakarta.

. (2016). Permendikbud Nomor 23 Tahun 2016 tentang Penilaian Hasil Belajar

Oleh Pendidik Pada Pendidikan Dasar dan Pendidikan Menengah. Kementrian Pendidikan dan Kebudayaan RI, Jakarta.

Kementerian Pendidikan dan Kebudayaan Edisi Revisi. (2017). Bahasa Indonesia SMP/MTs. Kelas VIII.

Khoiri, N. (2014). "Pengembangan Perangkat Penilaian Pembelajaran Menulis Karya Ilmiah (Bahasa Indonesia) untuk Siswa SMP".

Kosasih. (2011). Dasar-Dasar Keterampilan Bersastra. Bandung: Yrama Widya.

Kunandar. (2014). Penilaian Autentik (Penilaian Hasil Belajar Peserta Didik Berdasarkan K13). Jakarta: Grafindo.

Kusaeri. (2014). Acuan dan Teknik Penilaian Proses dan Hasil Belajar dalam Kurikulum 2013. Yogyakarta: Ar-Ruzz Media

Laily, et al (2015) Analisis Soal Tipe Higher Order Thinking Skill (HOTS) dan Soal UN Kimia SMA Rayon B Tahun 2012/2013.

Mardapi, D. (2008). Teknik Penyusunan Instrumen Tes dan Nontes. Mitra Cendekia, Yogyakarta.

Matondang, Z. (2009). Validitas Dan Reliabilitas Suatu Instrumen Penelitian. Junal Taburasa PPS Unimed. Vol 6 No 1 (online).

Mohammed, et.al (2015:13-20) in The Malasyan Online Journal of Educational Science

Muslich, N. (2008). KTSP Dasar Pemahaman dan Pengembangan. Jakarta: Bina Aksara. 2011. Pendidikan Karakter: Menjawab Tantangan Krisis Multidimensional. Jakarta: Bumi Aksara.

Narayana, S. \& Adithan, M. (2015). Analysis of Question Papers in Engineering Caourse with Respect to HOTS (Higher Order Thinking Skills). American Journal of Engineering Education (AJEE), Vol.6, No.1, p:1-10.

Nitko, A.J. \& Brookhart, S.M. (2011).Educational Assesment of Student. Xth edition. Upper Saddle River, New Jersey: Prentice Hall Engelwood Cliffs.

Nurgiyantoro, B. (2013). Penilaian Otentik dalam Pembelajaran Bahasa. Yogyakarta: Gadjah Mada University Press.

. (2012). Penilaian Pembelajaran Bahasa Berbasis Kompetensi. Yogyakarta: BPFEYogyakarta.

. (2010). Penilaian Pembelajaran Bahasa Berbasis Kompetensi. Yogyakarta: BPFEYogyakarta

Nuriadin, Ishaq and Krisna Satrio Perbowo. (2013). Analisis Korelasi Kemampuan Berpkir Kreatif Matematik terhadap Hasil belajar Matematika Peserta Didik SMP Negeri 3 Luranggung Kuningan Jawa Barat. Jurnal Ilmiah Program Studi Matematika STKIP Siliwangi Bandung.2 (10), 65-74

OECD. (2014). PISA 2015: Science competencies for tomorrow world volume 1: Analysis. Rosewood. Drive: OECD.

Oemar, H. (2011). Kurikulum Dan Pembelajaran. Jakarta: PT Bumi Aksara.

Patriawan, H., D. (2012). "Pengembangan Penilaian Teknik Servis Backspin Forehand dan Backhand Atlet Tenis Meja Yunior Klub Jusma Table Tennis School Yogyakarta". Skripsi S1. Yogyakarta: Program Studi Pendidikan Kepelatihan Olahraga, FIK UNY.

Permendikbud No. 20 Tahun 2007 tentang Sistem Pendidikan Nasional. 
Budapest International Research and Critics in Linguistics and Education (BirLE) Journal

Volume 2, No 4, November 2019, Page: 315-328

e-ISSN: 2655-1470 (Online), p-ISSN: 2655-2647 (Print)

www.bircu-journal.com/index.php/birle emails: birle.journal@gmail.com birle.journal.qa@gmail.com

Permendikbud No 23 Tahun 2016 tentang Penilaian Hasil Belajar oleh Pendidik

Permendikbud No. 53 Tahun 2015 tentang Penilaian Hasil Belajar oleh pendidikan

Permendikbud No. 66 Tahun 2013 tentang Standar Penilaian Pendidikan.

Permendikbud No. 81A Tahun 2013 tentang Implimentasi Kurikulum Pedoman Umum Pembelajaran tentang Penilaian Hasil Belajar oleh Pendidikan pada Pendidikan Dasar dan Pendidikan Menengah.

Permendikbud No. 104 Tahun 2014 tentang Penilaian Hasil Belajar oleh Pendidikan pada Pendidikan Menengah.

Poerwanti, E. et.,al. (2008). Bahan Ajar Cetak Asesmen Pembelajaran SD. Direktorat Jendral Pendidikan Tinggi Departemen Pendidikan Nasional, Bandung. 9-39 hlm.

PP No. 19 Tahun 2015 tentang Standar Pendidikan Nasional.

Prodopo, R.,D. (2012). Pengkajian Puisi. Yogyakarta: Gadjah Mada University Press.

Purwanto. (2009). Evaluasi Hasil Belajar. Surakarta: Pustaka Belajar.

Putra, N. (2012). Research \& Development Penelitian dan Pengembangan: Suatu Pengantar. Jakarta: Rajawali Pers.

Rochmah, N., L \& Asih Widi Widiastuti. (2015). Analisis Soal Tipe Higher Order Thingking Skill (HOTS) dalam Soal UN Kimia SMA Rayon B Tahun 2012/2013. Kaunia. Vol 11. No 1: 27-39. Diakses pada tanggal 20 Agustus 2018

Roekhan. (1991). Menulis Kreatif: Dasar-dasar dan Petunjuk Penerapannya. Malang: YA3 Malang.

Samosir, Tiorida. (2013). Apresiasi Puisi. Bandung: Yrama Widya.

Sani, Ridwan Abdullah. (2016). Penilaian Autentik. Jakarta: Bumi Aksara.

Sopandi. (2010). Memahami Puisi Perpustakaan Nasional. Bogor: Gramedia.

Sudjana, Nana. (2011). Penilaian Hasil Proses Belajar Mengajar. Bandung: Rosdakarya.

Sudijono. (2008). Pengantar Statistik pendidikan. Jakarta: RajaGrafindo Persada (2013). Pengantar Evaluasi Pendidikan. Jakarta: Rajawali Press.

Sugiyono. (2015). Metode Penelitian Kuantitatif Kualitatif dan $R \& D$. Bandung: Alfabeta. (2010). Metode Penelitian Pengembangan. Bandung: Alfabeta.

(2013). Metode Penelitian Pendidikan Pendekatan Kuantitatif, Kualitatif, dan R\&D.

Bandung: Alfabeta

Suherman, E. (2003). Evaluasi Pembelajaran Matematika. JICA UPI, Bandung.

Sunarti dan Rahmawati, Selly. (2014). Penilaian dalam kurikulum 2013. Yogyakarta: Andi

Surapranata, Sumarna. (2006). Analisis, Validitas, Reliabilitas dan Interpretasi Hasil Tes. PT.

Remaja Rosda Karya, Bandung.

2009. Analisis, Validitas, Reliabilitas dan Interpretasi Hasil Tes. Edisi Revisi. PT.

Remaja Rosda Karya, Bandung

Tegeh, Made et al. (2014). Model Penelitian Pengembangan. Yogyakarta: Graha Ilmu.

Thorndike, R.L \& Hagen. (1977). Mesaurement and Evauation in Psychology and Education $4 e$. John Wiley \& Sons, Newyork.

Uno, Hamzah. (2014). Assesment Pembelajaran. Jakarta: Bumi Aksara.

Waluyo, Herman J. (1987). Teori dan Apresiasi Puisi. Jakarta: Erlangga.

Wardany, K., Sajidan, \& Murni R. (2015). Penyusunan Instrumen Tes Higher Order Thinking Skill Pada Materi Ekosistem SMA Kelas X. Seminar Nasional XII Pendidikan Biologi FKIP UNS 2015, Hal 538-543. portalgaruda.org/article.php? article $=375337 \&$ val $=4058 \&$ title $=$ Penyusunan $\% 20$ Instrum en\%20Tes\%20Higher\%20Order\%20Thinking\%20Skill\%20\%20Pada\%20Materi\%20E kosistem\%20SMA\%20Kelas\%20X. (Diakses pada tanggal 7 Agustus 2016) 
Wardoyo, Sigit Mangun. (2013). Teknik Menulis Puisi. Yogyakarta: Graha Ilmu.

Wellek, R., and Warren. (2015). Teori Kesusastraan. Jakarta: PT Gramedia Pustaka Utama.

Widana, I. (2017.) Modul Penyusunan Soal Higher order thinking skills(HOTS). Jakarta: Direktorat Pembinaan SMA Direktorat Jenderal Pendidikan Dasar dan Menengah Departemen Pendidikan dan Kebudayaan.

Wulan, Ratna Elis and Rusdiana, A. (2014). Evaluasi Pembelajaran dengan Pendekatan Kurikulum 2013. Bandung: Pustaka Setia.

Yamin, Martinis. (2013). Strategi dan Metode dalam Model Inovasi Pembelajaran. Jakarta: Gaung Persada Press group.

Yuliastanti. (2013). "Pengembangan Bahan Ajar Sastra dengan Pendekatan Kontekstual untuk Siswa Kelas VII SMP”. Skripsi S1. Yogyakarta: Jurusan Pendidikan Bahasa dan Sastra Indonesia, FBS UNY.

Yunus. (2015). "Aktivitas Menulis Cerpen Siswa Kelas V SD dengan Menerapkan Metode Sugesti-Imajinatif dengan Media Lagu.” Jurnal PGSD Kampus Biru.

Zira Fatmaira (2018) Pengembangan Instrumen Penilaian berbasis Kemampuan Berpikir Tingkat Tinggi (HOTS) untuk pembelajaran Teks Resensi pada Siswa Kelas XI SMA Negeri 5 Binjai 